\title{
EDUCATIONAL AND THERAPEUTIC APPROACHES WITHIN THE SYSTEM OF SECONDARY AND TERTIARY PREVENTION PROVIDED TO PERSONS ADDICTED TO HABIT-FORMING SUBSTANCES
}

\author{
Eva Šotolová
}

\begin{abstract}
Addiction behaviour, specifically abuse of and addiction to habit-forming substances, must be approached from multidisciplinary perspective. The text is focused mainly on programs of secondary and tertiary prevention in which special educators are involved. It contains fundamental information for educators working also in other areas than that of addictology, in view of the fact that the problem of abuse of habit-forming substances by adolescents in young offender institutions and youth detention centres has been increasing. Emphasis is put on crisis intervention, on minimization of health and social risks in low-threshold programs, on residential and follow-up care and on substitution programs.
\end{abstract}

\section{Keywords}

Addictology, habit-forming substances, Harm Reduction, contact centres, residential care, follow-up treatment programs, self-help organizations, substitution, crisis intervention

\section{Problem of Crisis as an Addiction Factor}

Crisis can be understood from social, philosophical, medical or psychotherapeutic perspective. Crisis is not an unambiguous phenomenon; it may be an emergency condition involving a threat to the individual, but also an opportunity for a positive change. Crisis can help the individual to get to a higher level in self-concept, selfeducation and relations to other people. Crisis is a situation that leads to a change of the common life style; it implies stress and endangers the balance. Crisis is perceived 
as a dramatic coping with mental, relational and other conflicts. The help provided to the individual in crisis is called crisis intervention. In a situation of crisis, the individual is increasingly open to external help; when the crisis is over, the openness to help and thus the readiness to changes gets weaker. A poorly mastered crisis situation leads to the mental threat syndrome. The mental threat syndrome arises in a situation in which the person cannot bear or master his/her subjective experience. Primarily the following experiences are in the foreground:

- the person is not able to cope with anxiety, both real and unreal;

- the person has an unbearable feeling of guilt based on subjectively poorly mastered remorse;

- the person has difficulty to cope with shame and inquity related to the unbearable feeling of self-image or unbalanced integrity.

There is only thin line between the mental threat syndrome and a mental disorder. As Cohen and Lazarus (in: Šebek, 1988) state, the loss of mental balance is manifested by the changed feeling of physical integrity, by the loss of healthy feeling, accompanied by changed self-concept, disturbed emotional balance, lose of confidence within social roles and tasks.

There is a difference between developmental crisis and pathological crisis. The developmental crisis is caused by a conflict of older mental structures with new ones in the course of the development. Each developmental crisis constitutes a precondition both for regression and for progression of the development. Developmental crises in themselves lead to some undermining of the stability of the mental structure achieved. Children manifest individual differences with respect to the progress of developmental crises. They are conditioned by constitution and by early experience. The importance of early stages of development and of the related crisis consists, among other things, in the fact that wrongly solved crises impede the progress of all subsequent developmental crises. Developmental debts intensify the regressive developmental tendencies and force the individual to step back and to finish the unfinished issues. That leads to a prolonged, never solved crisis, gradually acquiring the character of a pathological crisis that may persist all life long. Developmental crises may change to a pathological crisis. Its experience is not necessarily strong and alarming, but it can be noticed in chronic dissatisfaction, in immature relations to other people, in poorly controlled impulses, in inability to understand one's feelings, in inability to find a life goal, etc. The pathological crisis can be the result of combination of other factors. It can manifest an intensified neurotic conflict through a trauma, developmental interference and developmental crisis (Šebek, 1988).

"Anything from outside, disturbing the typical course of mental development, has the character of a developmental interference. Developmental interferences include chronically wrong educational procedures of the parents, long lasting disease, separation from parents inadequate to age, excessive load put on the child at school or at home, 
growing up in a single-parent family, as well as other influences. Developmental interferences occur even in adulthood. For example, when the individual cannot apply his or her education for external causes in the long term; when the woman cannot implement her mother role, etc. Developmental interferences usually have the character of micro-traumatization; they are sometimes called cumulative traumas." (Šebek, 1988, p. 8)

\section{Drug Addicts and the Methods of Their Treatment}

The drug abuse is different in every individual, every group, generation or culture. It changes in the same individual depending on time. Addict persons abuse different drugs in different social and cultural environments with different results, in different amounts and for different reasons. Therefore, the solution cannot be simple. The solution of any problem involves a specific analysis of the problem. Similarly, to all other behaviours, which are multi-determined, the way of drug abuse is influenced by many factors. Family, school, crowd, mass media, the whole society. The influence of the family is considered primary by experts. Many drug addicts come from families which apparently function well, but only on the surface. The family does not or only inadequately fulfil the educational function. The general atmosphere in the family is important.

Presl, unanimously with American authors, points out the excessively careful, protecting education by mothers. Such inadequate education is as risky as any other extreme educational approach. It is manifested by abnormal dependence of the mothers on their children. Mothers often stagnate at an earlier education degree, tending to cleave to their children and to handle them as younger ones than they really are and assuming a protective attitude. The addict child is assigned a privileged role. The child is subject to considerable control and sometimes even indirect manipulation, related to strong emotional affection. Such attitude results from lack of understanding the need of the child's gaining independence. Fathers are described as standing aside, disinterested or even missing. Mutual relations between the father and the son are often described as completely negative in the families of addict persons.

Each of the pronounced educational attitudes provokes different, usually undesirable characteristics in the child.

American authors report a much higher number of pathogenic events in the family of an addict person than in the healthy population. The perception of the general pathogenic family atmosphere gets into the foreground. The affected individual is not able to cope with such stress and escapes to socially pathological behaviour. Such behaviour often constitutes a response to the crisis in the family. The drug addict person is afraid of separation from the family, but on the other hand, the family has the same feelings with respect to the drug addict. It is a process of mutual dependence, in which the addict's misdemeanour has had a protective function, aimed at maintaining the family cohesion. The family's need to "have him/her" has been equal to or greater than his/her need to 
have the family. As the family seems to need him/her very intensively, they exert pressure on him/her and tend to protect him/her against external influences. The family members do not acknowledge their own responsibility; they usually blame external systems for the addict's problems. The addict's behaviour diverts the parents' attention from their own problems - and dispels the family problem. Families of drug addicts often characterize themselves as closed, tight families.

The drug is expected to solve specific, mostly unconscious conflict situations that can be understood only based on the individual life story. The phenomena increasing the risk of becoming ill include low frustration tolerance, insufficient processing of affects, relationship disorders. Sufficient control functions are not available. The consumption of drugs is attractive as they restore the feeling of existence, fight against low spirits, satisfies wishes and reduces fears. The value of drugs affects the following areas:

- suppression of impossible wishes,

- exclusion of morally critical functions, through reduction of perception sharpness, avoidance of resignation, humiliation and self-accusation,

- restoration of the state of child's irresponsibility, suppression of the desire for liberation from extreme feelings of obligation and blame,

- the consumption of drugs also includes an attempt to seek the identity. Such search often leads to the choice of negative identity (Frank, 1986).

We cannot say that a personality is predestined to develop addiction based on his/her characteristics. We only can determine some characteristics increasing the risk of the origination of the illness. A drug addict person who succumbs to the addiction both mentally and physically loses the ability to perceive the reality as such. Such person's psyche deteriorates, the person is indifferent to own health and even risks death. Many addicts are unapproachable at the beginning of the therapy, they cover their feelings of fear, worthlessness and resignation. They are mostly mistrustful, they have lost the relation to themselves, to their family members and to the surrounding world. Drugs and many activities leading to acquire them, including criminal activities, have become the only contents of their life. To achieve positive results of re-education, the clients must cooperate. Many of them consider re-socialization unbearable and hard at the beginning. They resist, close themselves, sometimes interrupt the therapy hoping to manage it by themselves or to find a more pleasant therapeutic facility. Some of them must be excluded from the therapeutic program.

The will to common drugless life is considered one of the most important factors of the therapy. The foundation consists in common work, organizing of activities, continuous confrontation, mutual information, support, praise and criticism. Within the daily common life, individual and group therapy, the client acquires trust in the community and focuses on the group work. The clients assume responsibility and control each other, they gradually get independent, seek jobs and accommodation or return to their families and get gradually integrated into common life. The long lasting therapy triggers 
a developmental process during which the individual therapeutic goals are achieved one after the other. The client's motivation is the basic precondition of success.

\section{Motivational Interview in Therapeutic Approach}

Many clients come to the therapy with varying and conflicting motivations - so called ambivalence. "They know the risks, costs and damages related to their behaviour but, at the same time, they are bound to the drug abuse, which they consider attractive" (Miller \& Rollnick, 1991, p. 37).

An ambivalent individual has contrary or mixed feelings on oneself, the respective subject or idea, and is led in two mutually exclusive directions or to two contrary goals. It is important that the therapist approaches ambivalence as a natural phenomenon, accepts it and focuses on controlling it in the course of the therapeutic process. Miller combines elements of directive and non-directive psychotherapy in the motivational interview. It is a specific therapeutic style, developed to help the clients to decide and commit to the change. It is based on the strategy of humanistic therapy, cognitive-behavioural therapy, theory of systems and social psychology (Miller \& Rollnick, 1991).

\section{Basic principles of Miller's motivational interview}

Expression of empathy - empathic reflections are selectively used to strengthen the processes. Internal attribute - the responsibility for changes is born by the client. It is the recognized credit for the change achieved. External attribute is the opposite - in such case, the responsibility and the credit for the change is attributed to chance, external circumstances, illness and other factors. It has been proved that internally attributed changes are much more durable.

Insignificance of labelling - the therapist examines and reflects the client's perception without labelling and corrections. An acknowledgement and acceptance of the label of an addict during the motivational interview are not considered indispensable. The therapist focuses on the client's addiction-related problems and on their solution.

Avoiding of arguments - the motivational interview should help the client to learn to know the reality and to act accordingly. The therapist should not use any direct arguments, as they are deemed counter-productive. The client is considered a valuable source in the problem solution and has the right to choose his/her own goal and strategy of therapy. The therapist tries to initiate the client's problem solving process in a natural way. The motivational interview has a great importance in programs aimed at minimization of health risks.

Increase of own efficiency - it concerns the client's ability to get involved in the process of coping with a situation. The client is encouraged by the therapist to overcome obstacles and to achieve a behaviour change by emphasizing the client's own responsibility for 
making a decision to change. The client's self-confidence is strengthened. The therapist's task consists in offering different procedures to achieve the change. It is very important for the therapist to correctly distinguish the stage of the client's change process and to choose an adequate therapeutic intervention based on that (Miller \& Rollnick, 1991).

\section{The fundamental preconditions for the client's successful resocialization include:}

- acknowledgement of the need to change the current situation;

- acknowledgement of the addiction status;

- acknowledgement of the need of help;

- acceptance of the help offered;

- acknowledgement of the goal of abstinence;

- assumption of own responsibility for own life and effort to change it through active cooperation;

- acknowledgement of the purpose of general change of behaviour - creation of new behaviour patterns (Frank, 1986).

\section{When treating drug addicted persons, the success is based on a comprehensive system of resocialization programs consisting in:}

- field work;

- activities of low-threshold facilities like C-centres and other outpatient centres;

- detoxification wards of psychiatric clinics;

- therapy at psychiatric clinics or in therapeutic communities;

- educational and therapeutic approaches in day care centres;

- follow-up care indispensable to prevent relapses and provided in follow-up treatment centres and sheltered housing. The care system must include also substitution therapy intended for specific clients. The therapy is aimed at renouncing drugs, restoring physical and mental health and social and work integration in the society. The process is time and effort demanding. Individual therapeutic goals are achieved in a gradual manner.

\section{Harm Reduction - Focus on Tertiary Prevention}

Harm Reduction is an approach leading to reduce the negative effects of drug abuse. "The goal consists in minimizing the amount of suffering of the abuser and of the user's surrounding in the area of health, social and financial problems that may be related to drug consumption but are not implied in it" (O'Hare, 1992, p. 116). Harm Reduction is based on the assumption that the ideal goal of our intervention - lifelong total abstinence from drugswill always be totally unacceptable to a certain percentage of the users. Harm Reduction 
is aimed at achieving an individual change of the risk behaviour by making available the specialized services primarily in outpatient facilities in order to approach as many persons from hidden population as possible. That can be achieved within the programs of lowthreshold facilities, field and substitution programs. Field workers associate with drug users, establish contacts with them, acquire their confidence and carry out preventive interventions. The field work and programs of low-threshold facilities are aimed at establishing a permanent therapeutic relation and at winning the respective person to solve his/her risk behaviour within the programs in specialized facilities. Permanent and consistent abstinence constitutes an ideal solution, but such solution is unattainable to most addicts at the given moment. Therefore, a realistic approach should be applied, not aiming at the ideal, however little realistic solutions, but at solutions which reduce or minimize the harmful consequences of drug abuse (Heller \& Pecinovská, 1996).

Given the spreading of the HIV virus and of other transmissible diseases by drug users, the issue of general health of the drug users has been getting to the foreground, additionally to the emphasis on replacement and substitution programs. Public health was focused on fighting epidemics of different diseases and unsuitable life conditions in towns and villages in the $19^{\text {th }}$ century. In the $20^{\text {th }}$ century, issues of prevention were emphasized additionally to the individual life style. Stress was put on personal responsibility for own health. At present, the public health has been focusing more and more on the individual. Main trends consist in the individual's education, standardization and responsibility for own behaviour. All that is pervaded by the Harm Reduction approach, which is gradually penetrating from public health to other areas.

The programs aimed at minimization of health risks should include psychotherapeutic intervention. Individual facilities and programs for addicts combine elements of cognitivebehavioural and humanistic therapeutic schools.

\section{System of Ambulant, Institutional and Stationary Care For Addicts}

Outpatient therapy is characterized by regular visits of patients to AT advisory centres and other psychiatric outpatient facilities. The patients take part in group therapy and individual therapeutic interviews. They can also work in abstinence clubs, intended both for former and for current patients. The abstinence clubs (usually attended by a professional therapist) include therapy and hobby activities. Interesting forms consist in weekend therapies, intended for patients and their families. Partner groups are sporadically operated by some advisory centres. The therapeutic program is completed with professional lectures. Psychotherapeutic groups constitute the most important part of the therapy. The quality of their work depends on the therapist's personality and on the therapy applied.

Contact centre is a low-threshold facility where the clients are not registered under their names and birth numbers. The client only must give his/her name or nickname, age, type of the drug used and the kind of its use. The facility is focused on clients who 
are less motivated to undergo therapy. The C-centre activities are aimed primarily on reducing the health and social risks of the drug users. It is focused on ambulant therapy, first aid, consultancy and therapy within Harm Reduction - reduction of health and social risks resulting from the drug issues. Most services provided by the C-centre form part of tertiary prevention, care for persons using habit-forming substances and for persons addict to such substances. The fundamental program of the facility includes:

- contact work with drug users,

- crisis intervention,

- replacement program,

- basic health and sanitary service,

- minimum food and vitamin program,

- advisory services,

- operation of advisory and crisis hotline,

- reference testing of saliva to detect presence of HIV virus antibodies,

- basic social service.

Contact work with drug usersThe goal of the work consists in establishing contact, building confidence between the client and the contact worker and motivating the client to undergo therapy. Great emphasis is put on the reduction of risks related to drug abuse. Cooperation with people who do not use drugs but come into contact with the users (parents, other family members) is important as well.

Psychotherapeutic crisis intervention implies help to a person in need through psychological means. Two main goals of crisis intervention can be distinguished stabilization of personality and understanding the situation with respect to future. The person must not stay alone with his/her problems - he/she must carry hope into a change for the better when leaving the therapist.

Replacement program - replacement of used needles and syringes for sterile ones, accurate registration of injection tools and disposal of the used tools. Minimum food and vitamin program - offering of soup, baked goods, soft drinks, coffee. The health program includes provision of vitamins: vitamin C, Multi-tabs, Calcium-Magnesium. The program is being reduced in some contact centres.

Consultancy is focused on drug users. Provision of information on potential therapy and its conditions, detoxification and health care. Consultancy activities can be provided also to parents and persons who come into contact with the users. Consultancy and crisis intervention can be also provided by phone.

\section{Basic social service}

It includes primarily contacts with the family, with the school, authorities, consultancy when arranging documents, seeking job, housing, when asking for social benefits and 
unemployment support. Help in contact with courts and other social help. The social worker arranges places in the therapeutic community or in psychiatric ward for motivated clients. The clients are informed about the start of therapy. The client's decision is supported by the whole working team.

The Czech Republic does not establish application rooms yet. The first application room was established in Bern in 1987.

Great significance is attributed to field programs too. Field workers focus on clients with risk behaviour who are not motivated to change their behaviour. The field worker tries to get the client to the contact centre from the open drug scene, e.g. streets, parks, or closed drug scene - places inaccessible to the public, e.g. flats, squats. Programs provided just in the street are important.

\section{Institutional therapy}

Institutional therapy is more intensive than outpatient therapy. It involves several weeks of stay in the hospital in the psychiatric ward. The main components of the therapeutic program consist in detoxification with follow-up psychotherapy. The therapists make use of techniques and procedures suitable for patients of different types and applied in different stages of therapy. Their main characteristics are: permanent clients' exposure to the therapeutic influence, regime therapy (in alcoholic patients according to J. Skála's example implemented in the Apolinár Hospital). The therapy duration depends on the individual's situation (e.g. general health condition, duration of drug career, previous relapses, etc.).

\section{Therapeutic communities - development in the world}

"The idea of the therapeutic community emerged in Great Britain in the course of World War II. The war hardships brought many soldiers with reactive neurotic and psychosomatic disorders to British hospitals" (Kratochvíl, 1987, p. 8). The first therapeutic communities were intended for clients with mental health disorders (neuroses, psychoses, personality disorders, etc.). Such therapeutic communities were called "democratic". The therapeutic communities for clients addict to habit-forming substances are called "hierarchic". "The original, old type of therapeutic communities emerged in the English psychiatric hospital by the end of World War II" (Skála, 1987, p. 85). The therapeutic communities were based on the ideas of Maxwell Jones and Tom Maine who tried to implement a democratic system based on open communication of all community members.

"The new type started developing in 1958, primarily to cure addictions" (Skála, 1987, p. 85). The first therapeutic community for drug addicted persons was established in the United States in 1958 by Charles Dederich and called "SYNANON". Ch. Dederich continued developing the principles of Alcoholics Anonymous. "Most current 
communities for addict persons can find their roots in that organization. A detailed study of the development of Synanon can provide the workers of therapeutic communities with extraordinary knowledge on what is efficient and healing in a therapeutic community and what is dangerous and risky, on the other hand" (Kooyman, 1993 in Kalina, 2003, p. 54). The atmosphere of Syanon was objective at the beginning; later, Syanon got into a protracted crisis, become withdrawn from the world and considered it hostile. The crisis resulted primarily from Dederich's failure to cope with power and relapse. Syanon gradually turned into a sect directed by an autocratic leader who refused any criticism. In spite of that, the experience from Syanon inspired the creation of a number of communities in America and in Europe. Daytop Village (1963) and Phonix House (1968) are the best known of them. In Europe, there are communities like Daytop (Germany), Emiliehoeve (Holland) and other ones (Kalina, 2003).

The first therapeutic communities in Eastern Europe were established in Poland and called Monars. The first Monar was founded in Gloskow by Marek Kotaňski, a psychologist, in 1978. Marek Kotaňski was an important personality in the area of care for addicts, HIV positive persons and homeless persons. After the success of Monar in Gloskow, other communities were established in different parts of Poland with the help of former Gloskow clients and of the staff of the therapeutic community. Monar is a Polish nongovernmental organization aimed at helping drug addicts, HIV positive persons, AIDS patients, homeless persons and other groups of people in need of help.

\section{Therapeutic communities in the Czech Republic}

The term "therapeutic community" was used in our country in connection with addictions for the first time by Stanislav Kratochvil in 1971. He defines a therapeutic community as a "special form of intensive group therapy where the clients, usually of different ages, genders and education, live together for some time and, additionally to group sessions, share also common working and other program activities, which allows them to project problems from their own lives, primarily relations to people into such small model of society. The community has therapeutic character, as it allows, additionally to the above stated projection, also feedback on maladaptive behaviours, instigates acquisition of insight of own problems and of own share in creation of the problems, it should enable corrective experience and support training of more adequate and more adaptive behaviours" (Kalina, 2008a, p. 17).

The therapeutic communities are intended for long-term or middle-term therapy of different addictions to habit-forming substances. Kratochvíl lists the following principles of a therapeutic community:

- patients' active involvement in treatment,

- development of good communication at all levels between the clients, in side the therapeutic team and between the patients and the team, 
- increased equality of rights in decision making,

- social learning in which the community member gets feedback on the perception of his/her behaviour by others.

Therapeutic communities have specified behaviour rules; for example, no alcohol or other habit-forming substances are allowed; drug abuse results in exclusion. A serious breach of rules results in termination of the therapy, while a minor offence leads to degradation in the community hierarchy or other disadvantage. At the beginning, therapeutic communities were established exclusively in the area of public health in our country. The first specialized ward intended for research and therapy of alcoholism, known as Apolinár (one of the first facilities of its kind in the world), was established by Jaroslav Skála in 1948 at the psychiatric clinic. Since 2012, that ward for therapy of addictions is a part of the Addictology Clinic of the $1^{\text {st }}$ Medical School and General University Hospital in Prague. "Skála was probably the first worldwide to use the principles of a therapeutic and educational group in the area of addictions with success. The Apolinár or Skála model united the elements similar to the therapeutic community and behavioural or rather educational approaches. It is however not clear whether there was a connection between the first period of Apolinár and of M. Jones' and T. Maine's establishments in Great Britain. It can be taken for sure that in late 1940s, Skála was inspired by the knowledge from the area of education of socially disturbed youth by the concept of educational communities of A.S. Makarenko, a Ukrainian educator" (Kalina, 2013, p. 84). Kooyman lists A.S. Makarenko among the forgotten predecessors of therapeutic communities for drug addicts. "J. Skála has never completely clarified the sources and inspirations of his therapeutic system" (Kalina, 2013, p. 84).

In 1948, J. Skála established a sociotherapeutic club inspired by Alcoholics Anonymous and called it KLUS - Klub Lidí Usilující o Střízlivost (Club of People Striving for Sobriety). In 1951 he established the first sobering-up station worldwide. In 1967, together with E. Urban, a psychologist, and J. Rubeš, a psychiatrist, they used the principles of the therapeutic community to establish one of the top systems of psychotherapy training - SUR. Later, J. Skála was one of the originators of the system of theoretical education of psychotherapists at the Psychotherapeutic Faculty. He devoted all his life to his mission. In 1991, M. Těmínová and M. Vlček, special educators, established a therapeutic community for drug addicts in the village of Němčice near Strakonice, which gave origin to the SANANIM citizen association.

The treatment in that therapeutic community is intended for long-term therapy. It is divided into four stages. In the first stage, the client acquires confidence into the group and the community. The work at the client's motivation to abstinence is in focus. The client's motivation to own behaviour change is the foundation of successful resocialization. In the second stage, the client focuses on work in group and on training of responsibility. In the third stage, the client gets gradually more independent, searches housing and job and integrates into common life. The therapy in Němčice takes ten to fifteen months and it is aimed at making the clients cope with the challenges of day-to-day life: 
- get social and communication skills;

- assume responsibility for their decisions;

- acquire working habits;

- learn to solve challenging life situations;

- accept themselves;

- be satisfied and happy.

The long-term therapy in the therapeutic community is a strenuous but efficient process. A part of clients prematurely terminate the therapy in the community; some even do not start it. In 1998, the SANANIM citizen association established the therapeutic community in Karlov near Písek, with a middle-term program and therapeutic ward also for mothers with children. A comprehensive program for integration of the clients' family members and friends was processed in detail by the White Light therapeutic community. The community was established by J. Radimecký, a special educator. Other important communities include Podané ruce, Magdaléna, etc.

The therapeutic approaches used in the therapeutic community might not suit everybody. Some clients do not cope with the therapy, they leave the community or breach the rules and are excluded from the therapy, they can pass to another therapeutic program of a psychiatric hospital or to another therapeutic community. After some time, they can return to the same community.

At present, we can often see therapeutic approaches focused on specific clients, e.g. on young people placed to young offender institutions (YOIs) because of behaviour disorders. Such young offender institutions include: YOI Husův domov, section Poklad, Dvưr Králové; YOI Hostouň, separate unit Medvědí Kámen; YOI Čakovická, Prague 9 (Klíčov), separate unit Křešín; Youth detention centre Hodkovičky, Prague 4, separate unit "Cesta", Řevnice; YOI Žulová; YOI Pšov (we intentionally do not state the whole names of the individual facilities).

\section{Day care centre}

Day care centres are psychotherapeutic outpatient facilities for therapy of drug addictions. The facilities are visited by motivated clients whose institutional care can be substituted by outpatient care. The day care centre of SANANIM has been in operation since September 1996, as the first of its kind in the Czech Republic.

"The programs of the day care centre include a set of diagnostic, therapeutic and rehabilitation procedures, methods and techniques considering the client's current condition and needs:

- day care program in group for 12 persons at the maximum, taking 3 months,

- individual psychotherapy and family therapy, consultancy for parents and other family members,

- group therapy for the clients' parents and partners, 
- social work and consultancy,

- psychological and psychiatric examinations,

- differential diagnostics,

- club and leisure time activities for the clients" (Kalina, 1999, p. 18)

The day care centre closely cooperates with other programs of SANANIM. It continues the activities of the Contact centre and the Field programs, it precedes and sometimes replaces institutional or community therapy. The day care centre is followed up by the resocialization and follow-up treatment program of the Follow-up treatment centre.

\section{Follow-up care - follow-up treatment programs}

Follow-up treatment is not exactly defined; it is not determined when follow-up care is indicated, where it begins and ends. The follow-up treatment centre is a socio-therapeutic centre providing follow-up care for clients who have underwent a therapeutic program of some type and for those who have prematurely terminated the basic therapy or abstain from alcohol without having underwent a therapeutic program and are motivated to life without drugs.

The term "follow-up care" stands for many services used by the client after leaving the therapy. They include consultancy, psychotherapy, sheltered housing for clients who have no place to live or do not want to return to their family. They support and maintain abstinence after the end of the therapy.

Standards (Czech Cabinet Office, 2003) define the target population for follow-up treatment programs as "abstaining persons with medical history of addiction to habitforming substances with minimum suggested period of abstinence of 3 months and preference of persons who have undergone detoxification and at least a short-term therapy of outpatient or residential type with insight of and motivation to long lasting abstinence". The definition determines follow-up care as a service provided preferably to clients who underwent therapy in the past. However, there are clients who enter the follow-up treatment program without preceding professional help, with some awareness of their condition and with the need of help and support in abstinence (Kuda, 2003).

The basic set of clients has undergone a therapy.

"After the end of the therapy, the client is confronted with the challenges of daily life. It is a very difficult time, with increased probability of return to the original addicted behaviour. Therefore, the client, during follow-up treatment, gets particular support to build a new life without drugs. The support must affect some areas of the client's life. It is not psychotherapeutic work but social help (job, housing). It is a permanently valid 'daily life therapy'. The clients learn to assume all responsibility for their abstinence and life without drugs." (Kuda, 1999, p. 26)

The goal of the follow-up treatment centre consists in supporting the client in gradual integration into common life. Other goals include: prevention of relapse, finding job and housing, personal stabilization and finishing the therapeutic process, creation of 
a self-help community of abstaining clients (Kuda, 2003). The follow-up treatment centre includes sheltered housing. The flats are provided to clients who have underwent longterm therapy, do not have any place to live or do not want to return to their families. The conditions are: the client's abstinence, payment of rent, exercise of a job and participation in the afternoon follow-up treatment program. The goal of sheltered housing, i. e. a kind of "midway house", consists in helping the client to overcome the first months after the return from the therapy (Kuda, 1999).

\section{International self-help organizations}

\section{Alcoholics Anonymous}

"Alcoholics Anonymous are a community of women and men sharing the experience and hope to solve their common life and to help the others to recover from alcohol. The only requirement on membership consists in the wish to stop drinking. The Alcoholics Anonymous association is not linked to any sect, church, political organization or any other institution; it does not wish to get involved in any dispute; it does not support or contradict any third entity's programs. Their primary purpose consists in staying sober and in helping other alcoholics to achieve sobriety." (Alcoholics Anonymous, 1989)

This is the basic preamble of the movement that has set only one task: the fight against alcoholism. The Alcoholics Anonymous movement originated in the U.S.A. in 1935. It was established by two alcoholics who had been treated without success until then. In 1939, "The Big Book", the crucial work of the Alcoholics Anonymous is issued. AA observes "12 Steps" and "12 Traditions" containing specific instructions to cope with the problem of addiction to alcohol (from acknowledgement of defeat in relation to alcohol, to a honest balance of the present life, correction of errors and mistakes, to humility and help to other alcoholics who are still suffering). Twelve Steps and Twelve Traditions constitute the crucial part of the AA text:

\section{"Twelve Steps:}

1. We admitted we were powerless over alcohol (drugs, gambling) - that our lives had become unmanageable.

2. Came to believe that a Power greater than ourselves could restore us to sanity.

3. Made a decision to turn our will and our lives over to the care of God as we understood Him.

4. Made a searching and fearless moral inventory of ourselves.

5. Admitted to God, to ourselves and to another human being the exact nature of our wrongs.

6. Were entirely ready to have God remove all these defects of character.

7. Humbly asked Him to remove our shortcomings.

8. Made a list of all persons we had harmed, and became willing to make amends to them all.

9. Made direct amends to such people wherever possible, except when to do so would injure them or others. 
10. Continued to take personal inventory, and when we were wrong, promptly admitted it.

11. Sought through prayer and meditation to improve our conscious contact with God as we understood Him, praying only for knowledge of His will for us and the power to carry that out.

12. Having had a spiritual awakening as the result of these steps, we tried to carry this message to alcoholics, and to practice these principles in all our affairs.'

It should be pointed out that AA-type organizations are not linked to any specific religion and that the members include also atheists." (Kalina et al. 2003, p. 86)

\section{"Twelve traditions:}

1. Our common welfare should come first; personal recovery depends upon AA unity.

2. For our group purpose there is but one ultimate authority - a loving God as He may express Himself in our group conscience. Our leaders are but trusted servants; they do not govern.

3. The only requirement for AA membership is a desire to stop drinking.

4. Each group should be autonomous except in matters affecting other groups or AA as a whole.

5. Each group has but one primary purpose - to carry its message to the alcoholic who still suffers.

6. An AA group ought never endorse, finance, or lend the AA name to any related facility or outside enterprise, lest problems of money, property and prestige divert us from our primary purpose.

7. Every AA group ought to be fully self-supporting, declining outside contributions.

8. Alcoholics Anonymous should remain forever non-professional, but our service centres may employ special workers.

9. AA, as such, ought never be organized; but we may create service boards or committees directly responsible to those they serve.

10. Alcoholics Anonymous has no opinion on outside issues; hence the AA name ought never be drawn into public controversy.

11. Out public relations policy is based on attraction rather than promotion; we need always to maintain personal anonymity at the level of press, radio, and films.

12. Anonymity is the spiritual foundation of all our traditions."

(Alcoholics Anonymous, 1989, p. 7)

The AA meetings are held without attendance of professionals; they are always led by one of the longer abstaining alcoholics. The AA meetings can be either closed, i.e. only for alcoholics, or open, i.e. for alcoholics and those interested in the issue (family, friends, therapists). Multiple groups meet in the Czech Republic. The anniversary congress held in Montreal in 1985 was attended by fifty thousand persons from all over the world. AA have achieved recognition by professionals. Therapists and therapeutic institutions cooperate with them and motivate the patients to attend the meetings. 


\section{Self-help organizations operating in our country}

Our oldest club operating continuously is "KLUS", which stands for "Klub Lidí Usilujících o Střízlivost" (Club of People Striving for Sobriety), established by docent Skála. After 1948, it was not possible to establish an organization speaking about entrusting life to God's care in Czechoslovakia. Doc. Skála established an organization that used some elements of Alcoholics Anonymous, but counted with involvement of professional therapists as well. Socio-therapeutic clubs combine elements of self-help and help of professionals. They are mostly established at facilities specialized at addiction therapy in our country. The scope of club activities can be broad, from meetings of abstaining addicts to programs in which the addict can take part with the whole family or friends. The development of clubs dates back to late 1970s and has been continuing until the present.

Clubs and other self-help groups fulfil the mission of social psychiatry and sociotherapy, defined by the World Health Organization as follows:

"Provide the person affected and endangered by a mental disease with the opportunity to create social contacts beneficial for preservation or re-creation of adequate social behaviour. Their role consists in strengthening and maintaining the patient's interest in real social life and in real relations to people." (Bútora, 1989, p. 281)

The fundamental treatment of alcoholism without follow-up treatment, resocialization and rehabilitation usually bring only a short-term effect. Many alcoholics use their previous reference groups due to abstinence and feel a deficit in that sense. The club allows eliminating or mitigating the deficit at least temporarily. For lonely persons, it may even have the role of a primary social group. A long lasting and regular involvement in the club can be understood as a cultural change, as gradual acquisition of the culture of a new group. The club activities are not restricted to problems with alcoholism. Psychotherapeutic and sociotherapeutic procedures can be used also for other diseases, damages and stress situations. The goal of self-help groups consists in breaking out of social isolation, in achieving better social integration, in improving communication with other people (Bútora, 1989).

\section{Substitution therapy}

Substitution programs are intended for users of opiates (most frequently heroin). Substitution consists in replacing the illegal opiate by a legal opiate, aiming at mitigating the problems resulting from drug addiction, breaking up links to the illegal drug world, redirecting the client to a life style acceptable both for the client and for the society. Ideally, in achieving gradually full abstinence from drugs. Substitution therapy ranks among Harm Reduction approaches (minimization of health and social risks). It is a maintenance therapy, unlimited in time.

The preparations most frequently used in long-term maintenance substitution programs 
include methadon (Methadon), followed by buprenorphine (Buprenorphine). Methadon (Methadonum hydrochloridum) is a synthetic opioid, used orally in the Czech Republic. The first substitution program was started in the USA in 1964. In the Czech Republic, the first methadon program was started at the Apolinár clinic in 1997. During the first three years, it was a so called low-threshold program, intended for quite problematic drug clients. After the Centre for methadon substitution, DROP INem, o.p.s. was opened, the program started changing into a high-threshold program.

The low-threshold program is attended by the client every day, including weekends and holidays, to undergo continuous toxicological exams. If the exams repeatedly prove the presence of illegal substances, the client is excluded from the program for a month. However, some clients do not want to give up intravenous application of drugs, they use Pervitin, abuse alcohol and medicines.

The high-threshold program is intended for socially stabilized clients. The program involves clients having steady jobs or preparing for steady jobs, students, pregnant women, mothers with small children. The clients attend the program twice or three times a week and get the substitution substance for the remaining days to use it at home. Abstinence from illegal drugs is a condition and it is continuously checked. If a finding is positive, the client is put back into the low-threshold program.

"Forms of substitution therapy:

1. Short-term therapy (fast detoxification substitution, implemented most frequently during the stay in hospital and taking 1-2 weeks)

2. Middle-term therapy (extended detoxification, carried out during institutional treatment, sometimes during outpatient treatment; it takes several weeks to months; it is adequate for clients with very high tolerance or addict to several substances, which are discontinued or substituted gradually)

3. Long-term therapy, which is usually implemented in outpatient form - maintenance substitution, e.g. with methadon or buprenorphine for clients addict to opioids, which can take many months or years." (Popov in Kalina et al., 2003, p. 221)

The benefits of methadon as a substitution substance are listed by Parrino (1993):

1. "Methadon does not have euphoric, tranquilization or analgesic effect; the clients' consciousness or mood are not changed by using it, which allows normal social life.

2. The correctly specified methadon dose blocks the narcotic effect of other opioids, if they are used.

3. It does not lead to increased tolerance; so the substitution dose need not be increased, but remains stable.

4. Methadon is efficient even when used orally and it has an effect for 24-36 hours; it can therefore be applied $1 \mathrm{x}$ a day without syringe.

5. Methadon mitigates craving, which is stated to be one of the main motives of relapse.

6. When used in the doses intended for substitution, methadon is medically safe and non-toxic." (Popov in Kalina, 2003, p. 222) 


\section{Termination of methadon program}

Methadon is discontinued by gradual reduction of the daily dose; it usually has a longterm character. When undergoing detoxification from methadon, the critical stage with increased risk of relapse domes at a time when the dose drops below $25 \mathrm{mg}$ and the effect of the substance does not cover the 24 hours. The habit-breaking condition after methadon is usually weaker than after high heroin doses, but it is longer. "Methadon substitution reduces the use of heroin, criminality, risk behaviour related to injection use and premature deaths of opiate-addict persons" (Kalina, 2001, p. 65).

Buprenorphine substitution (based on thebain, an opium alkaloid) is carried out in form of sublingual tablets called Subutex and Suboxone. Subutex has been administered in the Czech Republic since 2001, Suboxone since 2008. "Suboxone contains, additionally to the active substance, i.e. buprenorphine, also naloxon that, if administered intravenously, provokes a strong antagonistic effect and abstinence syndrome. Thus the presence of naloxon should avoid intravenous abuse of the preparation. Buprenorphine can be prescribed by all physicians. If opiate-addicted persons are medicated by other preparations containing opioids, it is not a lege artis executed substitution therapy" (Randák, 2005 in Adiktologie 2011/3, p. 137).

Verster and Bunning (2004) describe the benefits of correctly provided substitution therapy. The benefits include reduced risk behaviour, improved physical, mental and social condition of the client. Infectious diseases like hepatitis B and C and HIV occur less frequently; mortality, particularly that resulting from overdosage, decreases. The life of the client and of the client's family achieves higher quality; public expenses on health care and criminal system decrease.

\section{References}

Alcoholics Anonymous. (1989). New York City.

Bútora, M. (1989). Mne sa to nemóže stat. [This Can't Happen to Me]. Martin: Osveta.

Frank, H. (1986). Kinder ohne Perspektive. Berlin.

Heller, J., \& Pecinovská, O. et al. (1996). Závislost známá a neznámá. [Addiction Known and Unknown]. Prague: Grada Publishing.

Kalina, K. et al. (2001). Mezioborový glosář pojmů z oblasti drog a drogových závislostí. [Interdisciplinary Glossary of Concepts of Drugs and Drug Addictions]. Prague: Úřad vlády ČR [Czech Cabinet Office].

Kalina, K. et al. (2003). Drogy a drogové závislosti 1 a 2. [Drugs and Drug Addictions 1 and 2]. Prague: Úřad vlády České republiky [Czech Cabinet Office]. 
Kalina, K. (2008a). Terapeutická komunita. [Therapeutical Community] Prague: Grada Publishing.

Kalina, K. (2008b) Základy klinické adiktologie. [Basics of Clinical Addictology]. Prague: Grada Publishing.

Kalina, K. (2013). Terapeutické komunity v České republice. [Therapeutical Communities in the Czech Republic]. Adiktologie [Addictology],13(2), 83-88.

Kalina, K. et al. (2015). Klinická adiktologie. [Clinical Addictology]. Prague: Grada Publishing.

Kratochvíl, S. (1987). Psychoterapie. [Psychotherapy]. 3rd edition, Prague: Avicenum.

Kuda, A. (1999). Doléčovací centrum. [Follow-up Treatment Centre]. In Výroční zpráva o.p.s. SANANIM [Annual Report of SANANIM, CSO].

Kuda, A. (2003). Následná péče, doléčovací programy. [Follow-Up Treatment, Follow-Up Programmes]. In K. Kalina et al. (Ed.), Drogy a drogové závislosti. Mezioborový přístup. [Interdisciplinary Glossary of Concepts of Drugs and Drug Addictions] (pp.208-214). Prague: Úrad vlády České republiky [Czech Cabinet Office].

Miller, W. R., \& Rollnick, S. (1991). Motivational Interviewing. New York: Guildford Press.

O'Hare, P. A. et al. (1992). The reduction of drug - related harm. Routledge.

Popov, P. (2003). Programy metadonové a jiné substituce. [Methadone Programmes and Other Substitutions]. In K. Kalina et al. (Ed.), Drogy a drogové závislosti. Mezioborový prístup. [Interdisciplinary Glossary of Concepts of Drugs and Drug Addictions] (pp.221226). Prague: Úřad vlády České republiky [Czech Cabinet Office].

Presl, J. (1995). Drogová závislost. [Drug Addiction]. 2d Edition, Prague: Maxdorf.

Randák, D. Výzkum charakteristiky a kvality života uživatelů substituční léčby Subutexem. [Research on the Characteristics and Quality of Life of Subutex Substitution Treatment Users], attestation thesis. Prague: Institut postgraduálního vzdělávání ve zdravotnictví [Institute of Postgraduate Medical Education]. as cited in Staňková, N., Vacek, J. (2011). Klient substituovaný buprenorfinem $v$ doléčovacích zařízeních $v$ kontextu skupinové psychoterapie [Clients on Substitution with Buprenorphine in Aftercare Facilities: The Group Therapy Context]. Adiktologie [Addictology], (11)3, 134-141.

Rotgers, F. et al. (1999). Léčba drogových závislostí. [Drug Addiction Treatment]. Prague: Grada Publishing.

Skála, J. et al. (1987). Závislost na alkoholu a jiných drogách. [Dependence on alcohol and other drugs]. Prague: Avicenum. 
Skála, J. (1988). Alkohol a vy - pokyny pro nemocné. [Alcohol and you - instructions for the sick]. Prague: Avicenum.

Standardy odborné způsobilosti pro zařizení a programy poskytující odborné služby problémovým uživatelưm a závislým na návykových látkách. [Professional competence standards for facilities and programs providing expert services to problem users and addicted on addictive substances] (2003). Prague: Úřad vlády ČR [Czech Cabinet Office].

Šebek, M. (1988). O krizi a příbuzných stavech. [On Crisis and Relative States]. In Životní krize a psychoterapie. [Life Crisis and Psychotherapy]. Prague: Kabinet psychoterapie, Psychoterapeutická klinika FVL UK [Division of Psychotherapy, Psychotherapeutical Clinic of Faculty of Medicine of Charles University].

Verster, A., \& Bunning, E. (2003). Informace pro tvůrce drogové politiky o účinnosti substituční léčby závislosti na opiátech. [Information for drug policy makers on the effectiveness of substitution treatment for opiate addiction]. Prague: Úrad vlády České republiky [Czech Cabinet Office].

\section{Author}

doc. PaedDr. Eva Šotolová, Ph.D.

Faculty of Education, Charles University in Prague

Department of Special Education

Magdalény Rettigové 4, 11639 Praha 1, The Czech Republic

eva.sotolova@pedf.cuni.cz 